\title{
ARTICLES
}

\section{Faith Development Theory Revisited: The Religious Styles Perspective}

\author{
Heinz Streib \\ Universität Bielefeld, Germany
}

\begin{abstract}
Focusing on Fowler's (1981) faith development theory (FDT), this article presents a modification of structural-developmental theory of religion. The primacy of cognitive development as motor and guideline of religious development is called into question. The new model, the typology of religious styles, is aimed at accounting more fully for the life-history- and life-world-relatedness of religion, at its principal interactive, interpersonal origin and shape. Thus the phenomenologists Merleau-Ponty $(1962,1988)$ and Ricoeur $(1985 / 1988,1990 / 1992)$ who provide philosophical perspectives, Noam's (1985, 1988a, 1988b, 1988c, 1990) developmental perspective, which is based on interpersonality, as well as Rizzuto's $(1979,1991)$ view of the psychodynamic development of religion, play a significant role for the reformulation. An overview of styles is described and illustrated in a figure. References to results of empirical research are included, and an explanation of fundamentalism is outlined that follows from the religious styles perspective.
\end{abstract}

In Fowler's (1981) faith development theory (FDT), we have, on the one hand, an indispensable explanatory tool for the religious diversity of modernity and postmodern times - a diversity that is becoming even more diverse, as inner (biographical) and outer (societal) religious plurality is growing - spawning from new religious and fundamentalist orientations to a deep but rather diffuse hunger for spirituality. On the other hand, the faith development paradigm, with its focus on religious cognition and its almost unquestioned adoption of the structural-develop-

Requests for reprints should be sent to Heinz Streib, Universität Bielefeld, Fakultät TGKM, Postfach 100131, D-33501 Bielefeld, Germany. 
mental "logic of development," needs to be qualified in order to account for the rich and deep life-world- and life-history-related dimensions of religion—but also of fundamentalist turns. In my proposal of a classification of religious styles, I want to clear up part of this ambiguity and to try a new start in theory and research.

\section{CRITIQUE}

It is my view that cognitively based theorists have overlooked the central structuring activities of the self by defining the epistemic self as the sole representative of structure. In the process, I believe, the cart was placed before the horse, life history became content to the structure of the epistemic self. ... Epistemology replaced life history. (Noam, 1990, p. 378)

With these words, Noam stated the point of the problem. The metaphor of the cart (cognitive competencies), which the theories of cognition have placed before the horse (the life history), refers also and above all to the neglect of the emotional, psychodynamic dimension. This critique also concerns the cognitive-structural theories of religious development. A more substantial regard for the psychoanalytic and psychosocial would lead to displacement of the cognitive-structural view as the exclusive key theory. Noam's aim thus was "going beyond Piaget" (Noam, 1990). ${ }^{1}$

Briefly, I summarize the critique of FDT, which I stated elsewhere (Streib, 1991, 1997). It is justified to speak of reductions with regard to religious development whenever the cognitive developmental logic is deemed to be not only the central theme, but also the motor of religious development, thus excluding dimensions of content, experiences, and function of religion. The shift of emphasis to, even the overburdening of, cognitive development is one face of the coin; the other is the disregard for dimensions that are just as crucial for the constitution and development of religion:

- The psychodynamic-interpersonal dimension (the psychodynamic of the self-self relationship).

- The relational-interpersonal dimension (the dynamic of the self-Other relationship).

- The interpretative-hermeneutic dimension (the dynamic of the self-tradition relationship).

- The life-world dimension (the dynamic of the self-social world relationship).

I therefore plead in favor of removing an obstacle to more-perspectiveness on religious development: The primacy of the cognitive structures as motor and

\footnotetext{
${ }^{1}$ See also, Noam and Kegan (1982). One could also speak of converting the theories of religious development "from top down to bottom up," as Sutter and Charlton (1994) proposed for Piagetian theory.
} 
guideline of religious development should be terminated. We should stop placing the cart before the horse. Instead, life history and life world, as shall now be explained, should move into the focus of the developmental perspective on religion.

\section{CONTRIBUTIONS TO A MORE-PERSPECTIVE VIEW OF RELIGIOUS DEVELOPMENT}

Philosophically, the new perspective finds support in the writings of the French phenomenologists Merleau-Ponty (1988) and Ricoeur (1990/1992). Notwithstanding some differences of opinion, they contradict a developmental perspective that is associated with decentration, suggesting a different concept of decentration. ${ }^{2}$ For a path of "going beyond Piaget," Merleau-Ponty's (1988) lectures at the Sorbonne from 1949 to 1952 are of special importance because there, based on his phenomenological key concept of perception and of being-in-the-world, he develops, in explicit contrast to Piaget, ${ }^{3}$ a portrait of a unique logic in infancy and childhood-that thus contradicts its interpretation as prelogic, as Piaget would say - which leads to a new perspective on the development of language acquisition, of children's drawings, of their causality, and of their self-Other relationship.

One of the important contributions from phenomenology, as presented in Ricoeur's (1975/1981, 1981, 1985/1988, 1990/1992) and Merleau-Ponty's (1962, 1988) works, thus, is the decisive account for the primacy of the life world and of the Other - the internal and external Other. For a revision of FDT, I therefore refer to and make use of two developmental perspectives, which I understand as ways of genuine psychological explication of the primacy of life world and Other and from which I have adopted not only terminological but also conceptual decisions.

First, I include Noam's (1985, 1988b, 1988c, 1990) and Noam, Powers, Kilkenny, and Beedy's (1991) critiques and moderation of the exclusive attribution of developmental dynamic to the development of cognition, and their fresh approach to the developmental dynamic in terms of interpersonal relationships. Biography, in a broad, multiperspective understanding, redirects primacy to interpersonality, social relationships, and life world as the basis for life history. This has decisive implications for religious development.

Second, for my revision I refer to the psychodynamic tradition represented by Erikson's (1968) and Rizzuto's (1979, 1991, 1996) work and to their contribution to an understanding of life history. Rizzuto's contribution is of special importance because she has integrated the development of God representations into the psychodynamic view. Religious development appears in a new light when the

\footnotetext{
${ }^{2}$ For a more detailed account of Ricoeur's philosophy, including the problem of decentration-and its critical implication for FDT, see Streib (1991).

${ }^{3}$ For an extensive reconstruction of the dialog between Merleau-Ponty and Piaget that never took place (because Piaget did not respond to Merleau-Ponty), see Liebsch (1992).
} 
mother-child dyad is understood as the origin of religion, when the transitional space between caretaker and child and the transitional objects that arise here are assumed to be the origin of the God representations. Religion, then, is conceived as a basically interactive process; religious development can be correlated with the development of object relations in a psychoanalytic perspective.

I therefore appreciate the extensive references to psychoanalytic contributions about infancy and early childhood that Fowler (1996) included to offer a rich description of the early stages. Although I agree with this portrait of the origin of faith in early childhood, I suggest that this portrait of faith and faith development is expanded on the other stages or styles of faith, and I do not agree, without qualification, which I will explicate later, with Fowler's statement that the faith stages could still be "held to be invariant, sequential, and hierarchical"(p. 57).

The focus on interpersonality is common to both theoretical perspectives, which I refer to as key contributions to a revision of FDT: The relationship of the individual to interpersonal others in the social environment (external objects) and the relation to objects in terms of object-relations theory (internal objects) parallel each other and interrelate. Religious development is a complex process of entangled factors: of structural development, of schemata of interpersonal relationships, and of themata, which are presented to the individual by experiences—and sometimes traumas-in earlier life history and that may change and vary as the interpersonal, social, and societal relationships change over a lifetime. Thus the view that is closest to my perspective is the one by Noam (1988a, 1988c, 1990) who suggested understanding development as the complex interrelation of themata and schemata.

\section{DIMENSIONS OF A CONCEPT OF RELIGIOUS STYLE}

The revision of FDT rests on the assumption that interpersonal relationships and their psychodynamics are both indicators and promoters of religious development. The concept of style suggests placing more emphasis on the factors of life history and life world for religious development. Noam (1985; see also Noam, Powers, Kilkenny, \& Beedy, 1991) made use of the style concept in this sense. I shall explicate the concept of religious style by highlighting three of its most decisive dimensions: (a) the self-Other dynamic as related to the psychodynamic history of themata; (b) the narrative character of biography; and (c) the life-world aspect, which qualifies life history as milieu sequence.

Religious Styles, the Self-Other Dynamics, and the Psychodynamic History of Themata

Life history is determined by the dynamics of the Self-Other interaction. This interaction has its own history, which may coagulate into life themes or themata. Religious symbolization and ritualization are also means of expression; we use them to 
communicate something. ${ }^{4}$ Thus religious styles are rooted in life history; their roots are interpersonal. Inasmuch as interpersonality has a history, beginning with events lying far back, and has yielded certain patterns of religious communication and religious styles elaborated at that time, present styles should not be conceived of as emerging independently and suddenly in the here and now but rather as having their roots in life history. Such Self-Other dynamics in life-historical perspective thus implies the inclusion of psychodynamic patterns of explanation, as in Erikson's (1968) and Rizzuto's $(1979,1991,1996)$ perspectives.

It is possible to identify three interesting impulses in Fowler's (1981) theory in this regard: First, in his interpretation of the interview with Mary ${ }^{5}$ - the psychosocial perspective played the veritable role of a second pillar, emphasizing the psychodynamic, life history, but also the life world as psychodynamic resources here-Fowler gave theoretical and empirical prominence to Erikson's (1968) work. Second, Fowler (1987) took a significant step toward taking up psychodynamic models by correlating his own stages of faith with those of Kegan (1982). Third, Fowler (1996) adopted, at least for the early stages of faith, Rizzuto's (1979) approach, which mostly relies on Winnicott (1971) and Erikson for her own view of religious development in a psychodynamic perspective.

It would, however, be a decisive step forward to integrate the relevance of life themata as proposed by Noam $(1990,1996)$ into religious development as a whole. It must be expected that interpersonal experiences and formative life themata reemerge from the storage of our psychical resources. Such life themata thus represent a challenge to the competencies or schemata that we use to work on the themata in the present.

\section{Religious Style and the Narrative Character of Biography}

The significance of themata for religious development and for the preference for religious styles can be understood even better when we say they are a matter of scripts, of personal myths, of stories, and when we take into account that they are of narrative character. With regard to the formation of identity, it is possible to refer to Ricoeur (1985/1988) who analyzed our interwovenness within a fabric of stories as the ground for identity (Streib, 1994).

With regard to the cognitive-structural theories, the conclusion is this: Not only are operations and structures relevant for development but also narratives are significant for life history. This has already been pointed out by Freeman (1984,

\footnotetext{
${ }^{4}$ The character of religion as means to communicate something is also the starting point of Day's (1993) approach to a definition of religion.

${ }^{5}$ Fowler devoted an entire chapter to reproducing and interpreting this interview with a young woman (i.e., Fowler, 1981, chap. 22); see also, the evaluation of Nelson and Aleshire (1986).
} 
1985, 1991). For moral development theory, the approaches of a narrative reformulation ${ }^{6}$ have been concretized to a plea for a narrative turn (Day \& Tappan, 1996). The self-Other interaction has a narrative character dealing with narratively structured themata. Accordingly, a narrative turn should be proposed for the theoretical and empirical analysis of religious development and socialization. The communication of the present styles always is, at the same time, the telling of the genealogical story, using earlier story material; the consolidation of a present style embraces the narrative integration and retelling of earlier styles.

\section{Religious Styles and Life World: Life History as Milieu Sequence}

If a more-perspective concept of style is to be unfolded for religion, it is necessary to emphasize, besides its focus on life history, its life-world conditionedness as well. Localization within the life world, however, is only the alternate side of life-historical localization. As Grathoff (1995) states from a phenomenological and sociological perspective, biography is to be investigated "as milieu sequence and life context of the milieu." The preference for a religious style and its development grows within the web of the everyday life world, from the milieus constituting meaning intersubjectively. Within our line of argument, referring to the life-world perspective is of special corrective relevance for the theories of cognitive-structural development, which are — and not unjustly—reproached for favoring individualism. ${ }^{7}$ The sociophenomenological localization of religion and of religious styles has its point in a narrative perspective as well: in the particular attention to the narrativity of the life-world constitution and genesis of religion and its styles.

\section{THE RELIGIOUS STYLES PERSPECTIVE}

\section{Religious Styles: A Definition}

Summarizing the characteristics of a revised perspective on religious development in terms of religious styles, I shall give a condensed definition:

${ }^{6}$ For some years, Day has been working on a narrative reformulation of Kohlberg's $(1981,1984)$ moral development theory (see Day, 1991a, 1991b, 1991c, 1993).

${ }^{7}$ Broughton's (1986) and Hull's (1991) political and sociological critiques of Fowler's (1981) theory note that the developing individual, in Fowler's perspective, seems to have been detached from the social context; the references to the life world seem problematical, especially for the higher, postconventional stages. 
Religious styles are distinct modi ${ }^{8}$ of practical-interactive (ritual), psychodynamic (symbolic), ${ }^{9}$ and cognitive (narrative) reconstruction and appropriation ${ }^{10}$ of religion, that originate in relation to life history and life world and that, in accumulative deposition, constitute the variations and transformations of religion over a life time, corresponding to the styles of interpersonal relations.

A multilayeredness of religious styles, which can be designated as internal pluralism, corresponds to the determined more-perspectiveness. The so-called milestone model, brought into discussion by Loevinger (1976), is therefore better suited to illustrate religious style development than stage-wise, ascending models. The milestone model draws the respective style as a rising curve that descends again after a culminating point and persists on a lower level, whereas the subsequent styles attain their own climaxes. From such developmental perspective, there are no plausible reasons, either, why a certain style should not, at least as precursor, develop earlier than structural-developmental theories normally assume, but especially that a potential relevance of a certain style continues after its biographical peak.

This model not only qualifies the hierarchical order of stages but also it expresses the multilayeredness of religious orientations at a certain point in lifetime and questions the structural-developmental principle of invariant sequence and of structured whole. Hierarchy needs to be differentiated because, at a certain developmental phase, it may be the best thing for an individual to be embedded in a certain style, as Kegan (1982) powerfully pointed out; here, rather, the developmental task is working on and coping with the integration of previous styles. But there are also times of transition when we have to regard the following style better for the person, his or her religion, and psychic health. The claims of invariance and sequentiality need to be modified and the assumption of structured wholeness should be dropped for religious development, when we assume that the most decisive structuring power for the transformation of religion emerges from the themata-loaded domain of the interpersonal, the psychodynamic, and from social relationships.

\footnotetext{
${ }^{8}$ Modus indicates that it is, in the first place, the way, the structure, or the pattern that characterizes a certain style. Anyway, I avoid talking about structure because, in the family of structural-developmental theories, structure signifies very specifically the cognitive-operational structure and tends to confine the perspective to the structuralist marginalization of life world and life history.

${ }^{9}$ Psychodynamic reconstruction and appropriation refer to the task of religion, which means dealing and coping with themata and psychosocial challenges.

${ }^{10}$ Reconstruction and appropriation caution against (the misunderstanding of) a specific constructivist perspective that gives predominance or even exclusivity to the "constructive activity of the ego" (Fowler, 1980/1986), tending to ignore the (phenomenological) conviction that the individual's construction always relates to and relays on manifestations of religion that precede the individual meaning-maker (Streib, 1991).
} 


\section{Religious Styles: An Overview}

Because the religious styles are conceived of as different modi of reconstruction and appropriation of religion that parallel the interpersonal styles, the styles'descriptions follow Noam's (1988a, 1988b, 1988c, 1990, 1992) descriptions of interpersonal schemata. The graphical model that appears to be the most adequate to describe the individual development of religious styles is the model of accumulative deposition of layers (Figure 1).

Subjective religious style. The subjective religious style corresponds to Noam's (1988c, 1990) phase of the subjective-physical self in early childhood. Although the symbiotic relation to the caretakers still prevails, in that mirroring can take place and basic trust can emerge, egocentricity is the basic pattern-the infant regards him or herself as the center of the world. It is the phase in which the ambivalence of trust and mistrust is at stake; the healthy outcome of this phase is the development of basic trust.

The infant begins, according to Stern (1985), to develop "evoked companions;" the emergence of the subjective self gives rise to shared frameworks and fantasies. Thus in this style, corresponding to Fowler's (1981) intuitive-projective faith, fan-

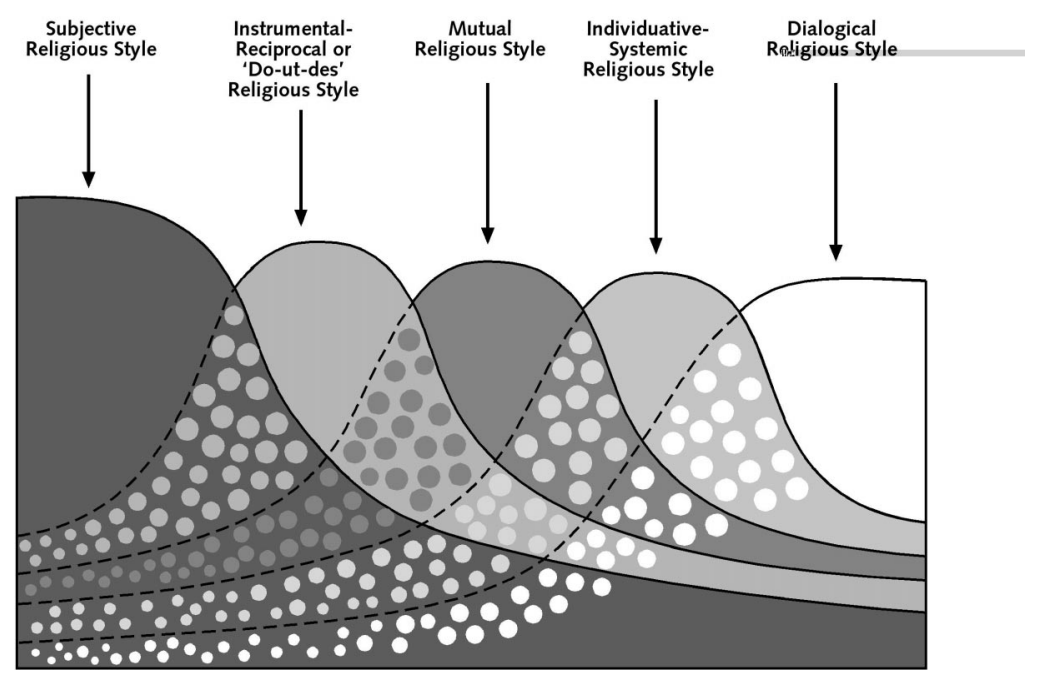

FIGURE 1 Religious styles. 
tasy, images, and feelings arise that in the course of further development play a continuous role. Intuition and impulsiveness however indicate playfulness and readiness for variation; the fantasies and images are always open for change and a new gestalt. This corresponds to the origin of religion and the development of the God representation in Rizzuto's (1979) terms: the representational object, as much it may owe to the specific child-caretaker relationship, is moving on to a variety of objects that may be "cathected."

Rizzuto's (1979) description of the emerging and developing God representation in early childhood directs attention to yet another dimension: When the God representation is seen to be shaped by idealized, and even aggrandized parental images, the image of The Almighty emerges, who is supposed to see and to punish. In the subjective religious style, we have to reckon with lawfulness and the judicious or, as Fowler (1996) says, of the "taskmaster deity who requires performance and perfection, or shame and guilt about failures" (p. 59).

Instrumental-reciprocal or "do-ut-des" religious style. The second style, the instrumental-reciprocal or "do-ut-des" religious style, makes use of the development of an inner self as distinguished from an outer self, when the child becomes aware of his or her own needs and interests as opposed to those of other people. Thus one's own needs and desires can become part of a reciprocal exchange. Noam's (1988c, 1990) "reciprocal-instrumental self" points to this structure. Also in regard to religion, the do-ut-des relationship is the basic pattern for both the interpersonal and the God-human relationship: "Good" is what God and the authority persons wish and demand; "bad" is what results in punishment and mischief; means of trade are obedience and fulfillment of religious commandments. The psychodynamic challenges concentrate on the crisis of "Initiative versus Guilt," but are also already on "Industry versus Inferiority." The God representation, to adopt Rizzuto's (1979) terms, concentrates on more or less aggrandized parental images.

Fowler's (1981) characterization of this style's pattern of understanding as "mythic-literal" described another aspect: Religious images and feelings are integrated in a story; myths play an important role. An awareness of the metaphoric or symbolic difference, however, may not be developed, which would allow us to change details of the story or religious rule. Literally everything happened precisely as told in the story; literally everything has to be observed exactly as the religious rules prescribe.

It is obvious that this description of the reciprocal-instrumental style- and the anxiety-laden, juridical dimension of the subjective style - portrays the fundamentalist worldview and attitude. However, we do not call children fundamentalists, but we regard these styles as adequate in infancy and childhood. Only their continuity or revival in adolescence and adulthood is the characteristic of fundamentalism, as will be explained later. 
Mutual religious style. The widening of the interpersonal horizon allows the emergence of a new religious style that rests on the mutuality of relationships in one's religious group and prefers an image of God as a personal partner. To be respected and loved by others is most important. Mutuality also is the soil in which altruism and overidentification with others may grow. The unquestioned security in one's religious group or the dependence on their judgment reveals that it is difficult to transcend the ideological and institutional group limits, and if one religious home has been left, another will be searched for desperately.

It deepens our understanding of the psychodynamic processes involved in the mutual religious style that "new objects" may join the originally cathected objects (Rizzuto, 1979), which could result in an "inestimable shifting." This helps to understand the sometimes severe changes in content, experience, and function of religion, especially in adolescence. Although these shifts and changes can be radical, the psychodynamics of mutuality is the prevalent modus and feature of this style.

Individuative-systemic religious style. The understanding of the social world as a system in which I have to take my position is the characterization of this style. Also, in religion — God, society, religious community, the human —all have their well-defined place and their role. Reflection on religious matters, the ability to give reasons for one's beliefs or skepticisms, is the cognitive aspect of this style. The negative effect of this kind of rationality for religious texts and rituals is that they are deprived of their symbolic quality and reduced to propositional statements.

It supports and deepens our understanding of the psychodynamic processes when we reckon with an "emotional distance from representations" and with a "critical reassessment" (Rizzuto, 1979) in the individuative-systemic style, whereas, at the same time, but rooted in the deeper layers of the psyche, there is the hunger for intimacy, identity, relatedness, and trust. This is the psychodynamic window for reinviting earlier styles for compensation.

Dialogical religious style. The dialogical religious style develops a new openness for the Other. Dialog here means that contradictions and differences do not result in exclusion and hostility toward others. When we are no longer predominantly concerned with finding and defending our own religious identity, we are able to open up to and learn from other people with religious orientations different from our own.

Here, also, a new openness and valuing of the symbol can develop that, according to Ricoeur (1975/1981, 1981), we could call "second naïveté." Ricoeur's concept of decentration may be even more powerful and add to our understanding of dialog: Decentration, according to Ricoeur, means that the subject is drawn into the power field of a symbol or narrative. "Decentration" means "letting-go" the self. This parallels Rizzuto's (1979) notion that, especially in adulthood, there can be an uncertainty about and a questioning of the God representations-with a pre- 
sentiment, however, that, whatever the representation, it may yield the presence of a trustworthy Other, a new emergence of basic trust.

\section{PLURAL PRESENCE AND THE REVIVAL OF RELIGIOUS STYLES: TOWARD A NEW EXPLANATION OF FUNDAMENTALISM}

At a certain time in life, a certain style appears to be prevalent and to structure most of the religious activity and correspondingly most of one's interpersonal and social relationships. Beyond the surface of everyday praxis and reconstruction, however, the previous styles are not eliminated, but rather they have disappeared and may have been forgotten. As in geological layers, where previous ages of our planet are invisible from the surface but nevertheless present and available, earlier religious styles are present and available in our psychic resources.

But unlike geological layers, earlier religious styles call for attention; they require working through and demand distanceation and integration; earlier orientations need revisiting and reflection. Under healthy conditions, this working through means both distanceation and integration in order to consolidate the present style. The ability to play with and deal with—reflexively and sometimes ironically—one's own and others' earlier styles is the indicator of a healthy integration. It means to tell and retell, to read and rewrite the story of one's own life in terms or symbols of religion.

In some cases, however, earlier religious styles are revitalized and regain part of their unquestioned and unreflected power over one's surface orientation and praxis. Using the geological metaphor again, I view this as conflict, fracture, and dislocation of religious styles and suggest calling this reemergence of earlier styles a revival of earlier religious styles. Most obviously this is the case in fundamentalist biographies.

I refer to the interpretation of fundamentalism here as one example of the innovative results of the religious styles perspective. To understand fundamentalists, we have to deal with puzzling questions like these: How does it fit together that a person, on the one hand, is able to deal with everyday situations successfully on the basis of practical reason and, for example, is able to design and control technological machines of high complexity-remember that a significant number of fundamentalists are graduates from our universities - and that the same person, in matters of collective and personal future, in matters of meaning, in matters of religion, resorts to the most simple answers, subjects to the grand simplificateurs? In terms of developmental theory, how can we understand that a person is able to perform formal operations in most domains of everyday life and that this same person takes every word of a guru or fundamentalist leader as the revelation of truth?

While traditional developmental theories lack an explanation because they do not account for regression but are assuming a "structural whole," the religious styles perspective suggests an understanding: Fundamentalism is the prevalence 
or the revival of literal understanding, of anxiety toward a taskmaster deity, of the do-ut-des juridical structure, a prevalence or revival of the reciprocal-instrumental style and part of the subjective style. ${ }^{11}$ These advance to shape the approach to religious matters, but other styles that have already been developed and are used in other dimensions of a person's life are not applied to religion. A conflict and fracture of styles occurs.

This could be demonstrated from the results of our biographical-reconstructive research projects on Christian-fundamentalist converts and deconverts ${ }^{12}$ and on adolescents who are fascinated with the occult. ${ }^{13}$ As our interview material suggests, many adolescents appear to have already moved beyond the modern paradigm in their religious development: It is not the nice, invariant teleological sequence, nor a structural whole, but rather style diversity and style revival.

The model that I have presented may help to understand not only the development of fundamentalism, but also its obstinate stability: The earlier styles not only reemerge, but also they become predominant in matters of religion. Parallel to the understanding of fundamentalism as "modern" antimodernism, ${ }^{14} \mathrm{I}$ do not regard the subjective and the do-ut-des styles as the same as they were in infancy and childhood, but later style patterns, mutual or systemic, merge with the reemerging residuals. Not only a revival but also a kind of "heterodyning" of styles takes place. This explains why the fundamentalist orientation is more stable, more rigoristic, and more cruel: It bestows the earlier styles with the power of mutuality in group relationships and the power of systemic-rational arguments, or both.

But this blend or heterodyning of religious styles is not completely stable. In some cases, the mutuality or the individuative reflectiveness resists complete submission and surrender to the fundamentalist demand. The person experiences a clash of styles. Especially, persons who are about to leave the fundamentalist orientation develop an awareness of the clash of styles, up to the point where it becomes intolerable, as our interview material demonstrates.

Healing, here, means to nurture and strengthen the present style of mutuality or individuative-systemic reflexivity and its application also in religion. Then the process of reworking earlier (fundamentalism-generative) style dimensions becomes possible. Case studies from our research also indicate such possibility. Here again, healing means the ability to tell and retell, to read and rewrite the story of one's life in one's latest available style. ${ }^{15}$

\footnotetext{
${ }^{11}$ Also, Fowler (1987) mentions such possibility.

${ }^{12}$ For research results and discussion, see Streib (2000b, 2001); for a brief summary in the official final report of the Enquête Commission, see Streib (1999b); for the more detailed research report, see Streib $(1998 ; 2000 a)$.

${ }^{13}$ For a brief summary, see Streib (1999a); for a full-length account of case studies, interpretation, and conclusions, see Streib and Schöll (2001).

${ }^{14}$ For the sociological interpretation of fundamentalism as "modern anti-modernism," see Küenzlen (1996). See also, Keupp (1994) and Drehsen (1994).
} 


\section{CONCLUDING REMARKS}

A philosophical footnote to close: It cannot be overlooked that the cognitive-structural theories of development, in their traditional shape of structural, hierarchical, sequential, and irreversible logic of development are due to an all too optimistic interpretation of the project of modernity. If unchanged, they cannot provide us with an explanatory framework for understanding fundamentalism and individual fundamentalist revivals. The modification of the developmental model, which has been presented, takes account of the fact that the project of modernity is exposed to grave disturbances. I am thus sketching the developmental psychology variant of a fundamental problem of modernity: the smooth teleological meta-story of modernity 16 - and the respective meta-story of development obliged to it —is challenged and impelled to modify by postmodern disturbances. Such disturbances also include individual and global fundamentalisms that again are based to no small degree on meta-stories themselves.

The religious style perspective suggests an answer to these postmodern challenges and opens a perspective of development and transformation beyond the fundamentalist revivals. It is well understood as the attempt to account for the comprehensive paradigmatic shift and revision - that exceeds, of course, the domain of religion and of cognitive development: the shift from disconnected reason to relational knowing, from universality to bodily being-in-the-life world, from objectivity to object relation, from decentrated subjectivity to openness for the Other. Or, to recall some names: to revise Piagetian structural teleology with Ricoeur's (1985/1988, 1990/1992) and Merleau-Ponty's $(1962,1988)$ phenomenology.

\section{ACKNOWLEDGMENT}

A version of this article was presented at the Annual Convention of the American Psychological Association, August 1999 in Boston.

\section{REFERENCES}

Broughton, J. M. (1986). The political psychology of faith development theory. In C. Dykstra \& S. Parks (Eds.), Faith development and Fowler (pp. 90-114). Birmingham, AL: Religious Education Press.

Day, J. M. (1991a). Knowing the good and doing it: Moral judgement and action in young adult narratives of moral choice. In D. Garz, F. Oser, \& W. Althof (Eds.), Der Kontext: Moralisches Urteilen-Moralisches Handeln. Frankfurt, Germany: Suhrkamp.

\footnotetext{
${ }^{15}$ For an approach to pastoral care and counseling with ex-members of fundamentalist groups, based on the concept of narrative revisiting and reworking of earlier styles, see Streib (2000c).

${ }^{16}$ See, for example, Lyotard's $(1984,1988,1993)$ designation of this mega-story as "negative entrophy."
} 
Day, J. M. (1991b). The moral audience: On the narrative mediation of moral "judgement" and moral "action." In M. Tappan \& M. J. Packer (Eds.), Narrative and storytelling: Implications for understanding moral development (pp. 27-42). San Francisco, CA: Jossey-Bass.

Day, J. M. (1991c). Role-taking revisited: Narrative and cognitive-developmental interpretations of moral growth. Journal of Moral Education, 20, 305-315.

Day, J. M. (1993). Speaking of belief: Language, performance, and narrative in the psychology of religion. The International Journal for the Psychology of Religion, 3, 213-229.

Day, J. M., \& Tappan, M. B. (1996). The narrative approach to moral development: From the epistemic subject to dialogical selves. Human Development, 39(2), 67-82.

Drehsen, V. (1994). Zwischen Wahlzwang und Fundamentalismusneigung. Die Religiösität Jugendlicher in kritischer Distanz zur Kirchlichkeit [Between the imperative to choose and tendency toward fundamentalism. Adolescent religion in critical distance to church membership]. In Wie religionsfähig ist die Volkskirche? Sozialisationstheoretische Erkundungen neuzeitlicher Christentumspraxis (pp. 66-91). Gütersloh, Germany: Kaiser.

Erikson, E. H. (1968). Identity, youth and crisis. New York: Norton.

Fowler, J. W. (1986). Faith and the structuring of meaning. In C. Dyksra \& S. Parks (Eds.), Faith development and Fowler (pp. 15-42). Birmingham, AL: Religious Education Press. (Original work published 1980)

Fowler, J. W. (1981). Stages of faith. San Francisco, CA: Harper \& Row.

Fowler, J. W. (1987). Faith development and pastoral care. Philadephia: Fortress.

Fowler, J. W. (1996). Faithful change. The personal and public challenges of postmodern life. Nashville, TN: Abingdon.

Freeman, M. (1984). History, narrative, and life-span developmental knowledge. Human Development, 27, $1-19$.

Freeman, M. (1985). Paul Ricoeur on interpretation: The model of the text and the idea of development. Human Development, 28, 295-312.

Freeman, M. (1991). Rewriting the self: Development as moral practice. In M. Tappan \& M. Packer (Eds.), Narrative and storytelling: Implications for understanding moral development (pp. 83-102). San Francisco, CA: Jossey-Bass.

Grathoff, R. (1995). Milieu und Lebenswelt. Eine Einführung in die phänomenologische Soziologie und die sozialphänomenologische Forschung [Milieu and life-world. Introduction into the phenomenological sociology and socio-phenomenological research]. Frankfurt, Germany: Suhrkamp.

Hull, J. M. (1991). Human development and capitalist society. In J. W. Fowler, K. E. Nipkow, \& F. Schweitzer (Eds.), Stages of faith and religious development (pp. 209-223). New York: Crossroad.

Kegan, R. (1982). The evolving self. Problem and process in human development. Cambridge, MA: Harvard University Press.

Keupp, H. (1994). Die Suche nach dem Gehäuse der Hörigkeit. Sozialpsychologie des Fundamentalismus [The search for a home of bondage. Social psychology of fundamentalism]. Praktische Theologie, 29, 33.

Kohlberg, L. (1981). Essays on moral development, Vol. I. The philosophy of moral development. San Francisco, CA: Harper \& Row.

Kohlberg, L. (1984). Essays on moral development, Vol. II. The philosophy of moral development. San Francisco, CA: Harper \& Row.

Küenzlen, G. (1996). Religiöser Fundamentalismus-Aufstand gegen die Moderne [Religious fundamentalism-Rebellion against modernity]. In H. J. Höhn (Ed.), Krise der Immanenz. Religion an den Grenzen der Moderne (pp. 50-71). Frankfurt, Germany: Fischer.

Liebsch, B. (1992). Spuren einer anderen Natur. Piaget, Merleu-Ponty und die ontogenetischen Prozesse [Footprints of a different nature. Piaget, Merleau-Ponty and the onto-genetic processes]. Munich, Germany: Fink.

Loevinger, J. (1976). Ego development: Conceptions and theories. San Francisco, CA: Jossey-Bass. 
Lyotard, J. F. (1984). The postmodern condition: A report on knowledge. Minneapolis: University of Minnesota Press.

Lyotard, J. F. (1988). The difference: Phrases in dispute. Minneapolis: University of Minnesota Press.

Lyotard, J. F. (1997) A postmodern fable. In J. F. Lyotard (Ed.), Postmodern fables (pp. 83-101). Minneapolis: Univerisity of Minnesota Press.

Merleau-Ponty, M. (1962). Phenomenology of perception. London: Routledge.

Merleau-Ponty, M. (1988). Merleau-Ponty à la Sorbonne. Résumé de cours 1949-1952. Paris: Edition Cynara.

Nelson, C. E., \& Aleshire, D. (1986). Research in faith development. In C. Dykstra \& S. Parks (Eds.), Faith development and Fowler (pp. 180-201). Birmingham, AL: Religious Education Press.

Noam, G. G. (1985). Stage, phase, and style: The developmental dynamics of the self. In M. Berkowitz \& F. Oser (Eds.), Moral education: Theory and application (pp. 321-346). Hillsdale, NJ: Lawrence Erlbaum Associates, Inc.

Noam, G. G. (1988a). A constructivist approach to developmental psychopathology. In E. D. Nannis \& P. A. Cowan (Eds.), Developmental psychopathology and its treatment (pp. 91-121). San Francisco, CA: Jossey-Bass.

Noam, G. G. (1988b). Self-complexity and self-integration: Theory and therapy in clinical-developmental psychology. Journal of Moral Education, 17, 230-245.

Noam, G. G. (1988c). The theory of biography and transformation. Foundation for clinical-developmental therapy. In S. R. Shirk (Ed.), Cognitive development and child psychotherapy (pp. 273-317). New York: Plenum.

Noam, G. G. (1990). Beyond Freud and Piaget: Biographical worlds-Interpersonal self. In T. Wren (Ed.), The moral domain (pp. 360-399). Cambridge, MA: MIT Press.

Noam, G. G. (1992). Development as the aim of clinical intervention. Development and Psychopathlology, 4, 676-696.

Noam, G. G. (1996). High-risk youth: Transforming our understanding of human development. Human Development, 39, 1-17.

Noam, G. G., \& Kegan, R. (1982). Soziale Kognition und Psychodynamik: Auf dem Weg zu einer klinischen Entwicklungspsychologie. In W. Edelstein \& M. Keller (Eds.), Perspektivität und Interpretation (pp. 422-460). Frankfurt, Germany: Suhrkamp.

Noam, G. G., Powers, S. I., Kilkenny, R., \& Beedy, J. (1991). The interpersonal self in life-span developmental perspective: Theory, measurement, and longitudinal analyses. In P. B. Baltes, D. L. Featherman, \& R. M. Lerner (Eds.), Life-span development and behavior: Vol. 10 (pp. 59-104). Hillsdale, NJ: Lawrence Erlbaum Associates, Inc.

Ricoeur, P. (1981). The hermeneutical function of distanciation. In Hermeneutics and the human sciences (pp. 131-144). Cambridge, MA: Cambridge University Press. (Original work published 1975)

Ricoeur, P. (1981). Appropriation. In Hermeneutics and the human sciences (pp. 182-193). Cambridge, MA: Cambridge University Press.

Ricoeur, P. (1988). Time and narrative, Vol. III. Chicago: University of Chicago Press. (Original work published 1985)

Ricoeur, P. (1992). Oneselfas another. Chicago: University of Chicago Press. (Original work published 1990)

Rizzuto, A. -M. (1979). The Birth of the living God. A psychoanalytic study. Chicago: University of Chicago Press.

Rizzuto, A. -M. (1991). Religious development: A psychoanalytic point of view. In F. K. Oser \& W. G. Scarlett (Eds.), Religious development in childhood and adolescence (pp. 47-60). San Francisco, CA: Jossey-Bass.

Rizzuto, A. -M. (1996). Psychoanalytic treatment and the religious person. In E. P. Shafranske (Ed.), Religion and the clinical practice of psychology. Washington, DC: American Psychological Association.

Stern, D. N. (1985). The interpersonal world of the infant. New York: Basic Books.

Streib, H. (1991). Hermeneutics of metaphor, symbol and narrative in faith development theory. Frankfurt, Germany: Lang. 
Streib, H. (1994). Erzählte Zeit als Ermöglichung von Identität. Paul Ricoeurs Begriff der narrativen Identität und seine Implikationen religionspädagogische Rede von Identität und Bildung [Narrated time as possibility for identity. Paul Ricoeur's concept of narrative identity and its implication for talking about identity and bildung in religious education]. In D. Georgi \& H. G. Heimbrock (Eds.), Religion und die Gestaltung der Zeit (pp. 181-198). Kampen, The Netherlands: Kok.

Streib, H. (1997). Religion als Stilfrage. Zur Revision struktureller Differenzierung von Religion im Blick auf die Analyse der pluralistisch-religiösen Lage der Gegenwart [Religion as a question of style. On the revision of structural differentiation of religion in respect to the analysis of contemporary pluralist religion]. In N. G. Holm, E. Möde, \& H. Petri (Eds.), Archiv für Religionspsychologie (pp. 48-69). Göttingen, Germany: Vandenhoeck \& Rupprecht.

Streib, H. (1998). Aussteiger, Konvertierte und Überzeugte. Kontrastive Analysen zu Einmündung, Karriere, Verbleib und Ausstieg in bzw. aus neureligiösen und weltanschaulichen Milieus oder Gruppen sowie radikalen christlichen Gruppen der ersten Generation. / Milieus und Organisationen christlich-fundamentalistischer Prägung. In Deutscher Bundestag. Enquête-Kommission "Sogenannte Sekten und Psychogruppen" (Ed.), Neue religiöse und ideologische Gemeinschaften und Psychogruppen. Forschungsprojekte und Gutachten der Enquête-Kommission "Sogenannte Sekten und Psychogruppen" (pp. 108-157). Hamm, Germany: Hoheneck.

Streib, H. (1999a). Off-road religion? A narrative approach to fundamentalist and occult orientations of adolescents. Journal of Adolescence, 22, 255-267.

Streib, H. (1999b). Sub-projekt on "Biographies in Christian fundamentalist milieus and organizations" (The research project on "Drop-outs, converts and believers: Contrasting biographical analyses of why individuals join, have a career and stay in, or leave religious/ideological contexts or groups," Part III). In Deutscher Bundestag. Referat Öffentlichkeitsarbeit (Ed.), Final report of the Enquête Commission on "So-called sects and psychogroups." New religious and ideological communities and psychogroups in the Federal Republic of Germany (pp. 402-414). Bonn, Germany: Deutscher Bundestag.

Streib, H. (2000a). Biographies in Christian fundamentalist milieus and organizations. Report to the Enquête Commission of the 13th German Parliament on "So-called sects and psychogroups" (Results of the research project on "Drop-outs, converts and believers: Contrasting biographical analyses of why individuals join, have a career and stay in, or leave religious/ideological contexts or groups"). Bielefeld, Germany: University of Bielefeld, Evangelische Theologie.

Streib, H. (2000b). Is there a way beyond fundamentalism? Challenges for faith development and religious education. In L. J. Francis, J. Astley, \& M. Robbins (Eds.), The fourth R for the third millennium: Education in religions and values for the global future (pp. 177-199). Dublin, Ireland: Veritas.

Streib, H. (2000c). Seelsorge im Kontext fundamentalistisch-neureligiöser Gruppierungen [Pastoral care in the context of new religious and fundamentalist groups]. In C. Schneider-Harpprecht (Ed.), Zukunftsperspektiven in Seelsorge und Beratung (pp. 139-163). Neukrichen-Vluyn, Germany: Neukircheuer.

Streib, H. (2001). Biographical and religious development in Christian-fundamentalist converts and deconverts: A narrative approach. The International Journal for the Psychology of Religion [Under review].

Streib, H., \& Schöll, A. (2001). Wege der Entzauberung. Jugendliche Sinnsuche und Okkultfasziniation [Way of disenchantment. Adolescent search for meaning and the fascination for the occult]. Münster, Germany: Lit.

Sutter, T., \& Charlton, M. (1994). Soziale Kognition und Sinnstruktur [Social cognition and the structure of meaning]. Oldenburg, Germany: BIS.

Winnicott, D. W. (1971). Playing and reality. London: Tavistock. 